\title{
OBSERVATIONAL LIFE DRAWING AS A HOLISTIC TEACHING TOOL IN THE TIME OF MEMES / PRE-RESEARCH STUDY
}

\author{
Helena Blašková \\ Ph. D. student, Department of Art Education, Pedagogic Faculty, Charles University (Czech Republic)
}

\begin{abstract}
This pre-research study deals with the problem of fundamental relational paradigm of life drawing in contradiction to virtual experience and consumer life style. It looks into the question how to teach drawing in the time of social networks and fake news when the reality has become more and more fictional, without losing the transcendental and cognitive potential of drawing. It inquires how the two-dimensional pictorial culture and related visual symbols and memes influence perception and ability to draw and how the problem is felt by pedagogues and students of drawing themselves.

The core of the study is created by the author's past experience when working as an artist, pedagogue and curator; and from that experience also derives the used practical research method - A/r/tography. The topic is viewed from the perspective of holistic pedagogy, image theories and contemporary art studies and it works with the conception of graphic types by Jaromír Uždil and symbolic systems by Betty Edwards. These principles of art expression also relate to a collection of drawings by dozens of respondents, which is an integral part of the study and the author gained it during several years when she was working as a teacher.

The study is a part of a doctoral research, which deals with qualitative contexts of drawings according to reality and their didactic reflections. The research is performed at the Department of Art Education at the Pedagogic Faculty of the Charles University in Prague.
\end{abstract}

Keywords: Life drawing, art education, teaching tool, art-based research, visual symbols.

\section{Introduction}

In the contemporary Euro-American culture, which is based on the hegemony of eye and intellect and for which the result of each work is more important than the process itself, the manual observational drawing is not appreciated enough and understood well. Within the prevailing consumer and digital way of life, all our activities are more and more flooded by the fear of impreciseness, unclarity, accidentality and chaos, and creative and soulful activities have become mostly mechanical and mannerist process of imitating and cloning. We are losing the feeling for depth, for "the melody behind the lyrics".

The more we focus on various monitors, screens, tablets and other means of the two-dimensional pictorial culture, the more shallow our everyday lives become. Peripheral vision, which is very important for our perception and mental system mainly for the fact that it integrates us into the space and thus into our life, is replaced by focal vision, which makes us play only a role of a viewer. Manual drawing and sketching of reality bring us to the sensual contact with an object or space. In our imagination we hold an object in our hands and in our mind at the same time (Pallasmaa, 2009). We design the imagined and proposed picture in our consciousness and also in our unconsciousness by our whole body. At the same time, we become the part of the object and the observer. A creative process needs not only our whole sight, but the holistic approach; it means the full body and mind identification and compassion. Thanks to drawing we can copy, analyse or deconstruct, but we also create a relation to the environment, we learn empathy and we learn how to integrate.

In the time when the threat of ecological catastrophe hangs over our civilisation like Damocles' sword, it is important to blow the dust off the drawing according to the reality and to see it not only as an ancient craft, but also as the oldest cognitive tool. And as a possible strategy how to survive, which is supposed to connect us to physical reality and its fundamental existential quality, and which may prevent us from taking off into the realm of virtual or other worlds and from alienation from nature. 


\section{Basic characteristics, questions and project objectives}

Drawing according to reality is often understood as an academic art discipline and a basic skill capital of fine artists. However, the contemporary approach to drawing at schools of arts lacks transparency of methods and meaning. Due to mass expansion of photography and new media, and due to conceptual artistic theories, drawing has lost the position of the crucial discipline and has been relegated to the secondary status (Faure Walker, 2005). On the field of contemporary art, the vicarious image, drawing or painting according to the two-dimensional pictorial template has been dominating over the image according to the 3-D reality for the long time. At least from the half of the last century it has put on different forms, from conservative appropriations to ironic post-modern quotations or collage post-internet works, which exist in various levels and in various media. It is possible to say that creating according to photographs is the today's answer to the question how we see the nature - as a secondary media topic (Patočka, 1992). The nature is a mere image inside of the more powerful primary "nature“, inside the virtual contemporary society. Is it still possible to visualize the old topic of nature as a normal image (Ševčíková, Ševčík, 1996)? What can learning how to draw (not only according to models) constitute in our contemporary time?

This preliminary study is inspired by the efforts to clear up the philosophical background of contemporary art drawing and it tries to contribute to the discussion. It deals with the influence of virtual reality and symbolic pictorial matrices to visual literacy of non-professional viewer. It investigates how the two-dimensional pictorial culture and related visual symbols and memes influence the perception and ability to draw. The goal of the study is to find out how the students and pedagogues of art education see and approach the problem of copying, vicarious image and impact of pictorial matrices on the ability to draw and creativity itself.

In the context of the main focus of the author's doctoral studies, the goal of the whole project is to rehabilitate the life drawing as a universal, ecological and holistic teaching tool, and to map the difference of professional and folk discourse of drawing.

\section{Methodology and conceptual framework}

The study is a part of pedagogical art research and it derives from the introspection of the author's past experience as an artist, pedagogue and curator. The method that has been used is $\mathrm{A} / \mathrm{r} /$ tography, which, within gathering and analysis of data, as the only method enables an ambivalent approach and communion of roles - an artist / a pedagogue / a researcher (Irwin, R. (2004). An artist / researcher is able to articulate and clarify the understanding of the process from inside - out, that mans in a way that might not be so fundamentally approachable by a contrarily focused theoretician and scientist. In that context we can also see an advantage in the fact that an artist / teacher has deeper experience with a creative process in the course of its long-term development. Considering the new paradigm of art education, which has become influential in the last years and which has oriented students' attention not only inside, but mostly outside (from self-reflection and self-analysis to attention to surroundings, nature, local and global groups, media and also to communication itself, that means to various discourses) (Varto, 2006), the mentioned pluralism of roles is ideal.

The theoretical framework of the study is the intersection of chosen opinions from holistic pedagogy, contemporary art theories, image theories, phenomenology and post-continental philosophy (e.g. concepts of Alain Badiou or Isabelle Stengers). The concepts of visual symbolic systems or graphical types are based on the works by Betty Edwards, Jaromír Uždil and Helena Hazuková.

\section{References}

Irwin, R. (2004). A/R/Tography: Rendering Self Through Arts-Based Living Inquiry, Vancouver, Canada: Pacific Educational Press.

Pallasmaa, J. (2012). The Thinking Hand, Existential and Embodied Wisdom in Architecture I Myslicí ruka, Existenciální a ztělesněná moudrost v architektuře. Prague, Czech Republic: Archa.

Patočka, J. (1992). The Natural World as a Philosophical Problem / Přirozený svět jako filozofický problem. Prague, Czech Republic: Československý spisovatel.

Ševčíková, J., Ševčík, J., (1996). Moment on Focus / Okamžik zaostření. Prague: Gallery MXM

Varto, J. (2006). Art Education and multiple Strategies of Contemporary Art. In Sederhoml, H. (Ed.). (2012). Artbeat. Helsinki: Aalto Art Books 